\title{
Upaya Meningkatkan Kompetensi Guru dalam Penyusunan Proposal Penelitian Tindakan Kelas (PTK) melalui Workshop Tahun Pelajaran 2020/2021
}

\author{
Rosmaliwarnis Rosmaliwarnis ${ }^{1}$ \\ ${ }^{1}$ Unit Pelaksana Teknis Daerah Sekolah Menengah Pertama Negeri 2 Kecamatan Luak, Indonesia
}

\begin{tabular}{l} 
Article Info \\
\hline Article history: \\
Received Jun $18^{\text {h }}, 2021$ \\
Revised Jul $23^{\text {th }}, 2021$ \\
Accepted Aug $24^{\text {th }}, 2021$
\end{tabular}

\section{Keyword:}

Workshop

Kompetensi guru

Penelitian tindakan kelas

\begin{abstract}
Penelitian Tindakan Sekolah (PTS) ini bertujuan untuk mengetahui sejauhmana penerapan Workshop meningkatkan kompetensi guru SMPN 2 Kec. Luak dalam penyusunan proposal PTK. Penelitian ini diharapkan bermanfaat bagi guru dalam meningkatkan keprofesionalan guru melaksanakan tugas sehari-hari. PTS ini dilaksanakan selama dua siklus yang terdiri dari empat tahap: perencanaan, pelaksanaan, observasi dan refleksi. Indikator keberhasilan dalam penelitian ini adalah Guru SMPN 2 Kec. Luak guru mampu $80 \%$ menyusun proposal PTK dengan mencapai nilai rata-rata minimal Baik. Hasil yang diperoleh pada siklus II adalah sebagai berikut; 1) Peningkatan indikator proposal PTK dari siklus I ke Siklus II adalah 25,31\%. 2) Peningkatan kompetensi guru menyusun proposal penelitian secara individu adalah 27,25\% dengan hasil semua guru memperoleh nilai Baik. Oleh sebab itu, indikator keberhasilan telah terlampaui dan Penelitian Tindakan Sekolah (PTS) dinyatakan berhasil. Berdasarkan temuan penelitian, maka dapat disimpulkan bahwa Workshop sangat efektif dalam upaya meningkatkan kompetensi guru SMPN 2 Kec. Luak dalam penyusunan proposal PTK karena semua peserta Workshop (8 orang) berhasil menyusun proposal PTK sesuai harapan. Peneliti menyarankan kepada kepala sekolah sejawat untuk melakukan kegiatan pembimbingan di sekolah yang dipimpin untuk meningkatkan kompetensi guru dalam pengembangan keprofesian berkelanjutan (PKB).
\end{abstract}

(C) 2021 The Authors. Published by IICET.

This is an open access article under the CC BY-NC-SA license (https://creativecommons.org/licenses/by-nc-sa/4.0

\section{Corresponding Author:}

Rosmaliwarnis, R.,

Unit Pelaksana Teknis Daerah Sekolah Menengah Pertama Negeri 2 Kecamatan Luak, Indonesia

Email: rosmaliwarnis123@gmail.com

\section{Pendahuluan}

Guru adalah komponen yang sangat penting dalam sistem pendidikan. Peran guru sangat mempengaruhi perkembangan pendidikan. Maka agar sekolah sebagai organisasi pendidikan mampu menghadapi perubahan dalam menghadapi tantangan kehidupan modern, maka guru sebagai bagian yang tak terpisahkan dari sistem pendidikan perlu meningkatkan kemampuan diri secara terus-menerus.

Permendikbud No. 15 tahun 2018 menjelaskan bahwa guru adalah pendidik profesional dengan tugas utama mendidik, mengajar, membimbing, mengarahkan, melatih, menilai, dan mengevaluasi peserta didik pada pendidikan anak usia dini jalur pendidikan formal, pendidikan dasar, dan pendidikan menengah. Oleh sebab itu seorang guru dituntut untuk selalu mengembangkan kompetensi diri agar dapat memenuhi standar mutu terutama dalam peneingkatan kompetensi guru tentang pembelajaran di kelas yang diembannya. 
Kemendikbud (2016) menyatakan Pengembangan Keprofesian Berkelanjutan (PKB) untuk mendukung pengembangan profesi guru pembelajar. PKB merupakan salah satu unsur yang diperlukan dalam pemenuhan angka kredit yang dipersyaratkan untuk kenaikan jabatan fungsional guru. Selanjutnya, Kemendikbud (2019) tentang Pedoman Kegiatan Pengembangan Keprofesian Berkelanjutan (PKB) dan Angka Kreditnya. Pengembangan Keprofesian Berkelanjutan bertujuan untuk kenaikan pangkat guru sesuai dengan kebutuhan, bertahap, dan berkelanjutan. Pengembangan ini dalam rangka untuk meningkatkan profesionalisme guru. Salah satu publikasi ilmiah yang dapat dilakukan guru adalah dengan melakukan Penelitian Tindakan Kelas (PTK). Penelitian ini tidak mengganggu program kerja guru karena penelitian dilakukan pada kelas yang dianggap bermasalah dalam pembelajaran, baik permasalahan dari peserta didik maupun dari guru.

Kondisi nyata yang dihadapi oleh guru guru yang mengajar di SMPN 2 Kec. Luak, belum memiliki motivasi dan kemauan melaksanakan Publikasi ilmiah. Hal ini berdampak terkendalanya guru-guru dalam penyusunan bahan naik pangkat.

Alasan yang sering dikemukakan oleh guru guru di SMPN 2 Kec. Luak adalah bahwa dengan banyak jam mengajar yang dibebankan kepada guru maka mereka tidak punya waktu untuk membuat proposal/melaksanakan Penelitian Tindakan Kelas. Guru sibuk membuat perangkat pembelajaran, mengoreksi hasil kerja siswa, dan masih banyak lagi alasan-alasan yang disampaikan guru. Kebanyakan guru berfikir tidak menjadi masalah bagi mereka jika tidak naik pangkat. Pada hal sesungguhnya naik pangkat bagi seorang guru adalah sebuah prestasi kerja yang dapat dibanggakan baik bagi guru itu sendiri maupun sekolah.

Faktor penyebab terjadinya kondisi di atas antara lain, kurang pedulinya kepala sekolah selaku seorang pemimpin di sekolah. Kepala sekolah belum mendorong guru-guru yang kurang berminat mempelajari apa itu PTK secara maksimal. Penyebab yang lain berasal dari kebanyakan guru SMPN 2 Kec. Luak yang memang enggan mencoba untuk melakukan penelitian tindakan kelas. Kedua penyebab inilah yang menjadi faktor utama sehingga terjadi kondisi seperti yang telah dipaparkan di atas.

Berdasarkan permasalahan di atas, maka peneliti sebagai seorang kepala sekolah di SMPN 2 Kecamatan Luak berkeinginan melaksanakan penelitian tindakan sekolah dalam penyususnan proposal penelitian tindakan kelas bagi guru.

Peneliti memilih Workshop sebagai solusi adalah karena melalui Workshop pembelajaran yang sulit bisa menjadi mudah. Workshop bisa memecahkan permasalahan secara bersama-sama. Melalui Workshop juga dapat menjalin tali silaturrahim dan kekeluargaan yang tinggi antar sesama guru maupun kepala sekolah sebagai peneliti. Adapun judul Penelitian Tindakan Sekolah ini adalah: "Upaya Meningkatkan Kompetensi Guru SMPN 2 Kec. Luak dalam Penyusunan Proposal Penelitian Tindakan Kelas (PTK) melalui Workshop Tahun Pelajaran 2020/2021". Tujuan penelitian adalah untuk mengetahui efektifitas pelaksanaan Workshop untuk meningkatkan kompetensi guru SMPN 2 Kec. Luak dalam penyusunan proposal Penelitian Tindakan Kelas (PTK) semester dua tahun 2020/2021.

Hasil penelitian ini diharapkan dapat memberikan manfaat baik manfaat teoritis maupun manfaat praktis. Secara teoritis penelitian ini diharapkan memberikan manfaat untuk pengembangan teori yang berhubungan dengan upaya peningkatan kompetensi guru dalam membuat proposal PTK. Adapun manfaat praktis yang diharapkan dalam penelitian ini adalah sebagai berikut: bagi guru, kompetensi profesional guru dapat meningkat melalui pelaksanaan penelitian tindakan kelas, bagi Kepala sekolah, dapat membina guru dalam pengembangan keprofesionalan berkelanjutan guru untuk digunakan naik pangkat, bagi pengawas, ditemukan strategi pembinaan yang tepat dalam melaksanakan pelatihan untuk meningkatkan kompetensi guru dalam membuat proposal penelitian tindakan kelas, dan bagi sekolah, dapat meningkatkan mutu proses pembelajaran melalui peningkatan kemampuan guru dalam penelitian tindakan kelas.

\section{Metode}

Penelitian Tindakan Sekolah (PTS) adalah penelitian yang dilaksanakan oleh seorang Kepala Sekolah di sekolah yang dipimpinnya. Penelitian tindakan ini bertujuan untuk Pengembangan Keprofesian Berkelanjutan (PKB) bagi kepala sekolah. Dengan pelaksanaan Penelitian Tindakan Sekolah ini, seorang kepala sekolah dapat meningkatkan prestasinya dan juga dapat memperoleh poin dalam kenaikan pangkat. Oleh sebab itu, kepala sekolah dapat menjadi lebih kompeten dan berprestasi dalam memimpin satu sekolah.

Disamping itu, seorang kepala sekolah juga dapat membina guru-guru dalam penyelesaian tugas-tugas pokok mereka. Waitlem dan Risman (2017) menjelaskan bahwa PTS adalah sebuah penelitian yang dilakukan oleh Kepala Sekolah untuk meningkatkan kinerja sistem pendidikan dan mengembangkan manajemen sekolah supaya produktif, efektif, dan efisien. Selanjutnya, menurut Arikunto (2010), penelitian tindakan dilaksanakan dalam dua siklus, setiap siklusnya terdiri dari empat tahap yaitu: (1) perencanaan, (2) 
pelaksanaan, (3) pengamatan, (4) refleksi. Perencanaan adalah dimana seorang peneliti merencanakan subyek yang akan diteliti, merancang instrumen yang digunakan dalam penelitian dan menentukan jadwal penelitian. Peaksanaan dan Pengamatan dilaksanakan secara bersamaan berdasarkan perencanaan yang telah dirancang peneliti. Refleksi adalah perenungan yang dilakukan peneliti setelah selesainya pelaksanaan penelitian dalam satu siklus. Pada refleksi ini peneliti membahas keunggulan dan kelemahan yang ditemukan pada siklus tertentu.

Subjek penelitian ini adalah guru guru yang mengajar di SMP Negeri 2 Kecamatan Luak, baik yang sudah berstatus pegawai negeri sipil maupun guru honorer. Ada dua belas guru yang berstatus sebagai Pegawai Negeri Sipil dan empat guru honorer di UPTD SMPN 2 Kecamatan Luak. Sementara yang terlibat dalam penelitian ini adalah sebanyak delapan orang. Semuanya sudah berstatus Pegawai Negeri Sipil dan guru tetap di UPTD SMPN 2 Kecamatan Luak.

Penelitian ini dilaksanakan selama 4 bulan. Penelitian dimulai pada bulan Januari 2021 dan berakhir pada bulan April 2021. Penelitian diawali dengan perencanaan yang dimulai pada awal Januari 2021. Pada perencanaan ini, peneliti memberikan informasi tentang rencana pelaksanaan Penelitian Tindakan Sekolah tentang Penyusunan Proposal Penelitian Tindakan Sekolah. Pada kesempatan tersebut peneliti juga menyampaikan bahwa peserta diutamakan guru yang akan naik pangkat ke pangkat setingkat lebih tinggi. Siklus I dimulai hari Jumat tanggal 22 Januari 2021 dengan materi Sosialisasi dan penjelasan tentang Proposal Penelitian Tindakan Kelas (PTK) dan meminta guru menuliskan semua permasalahan yang ditemukan di kelas. Peneliti juga menayangkan beberapa metode dan strategi mengajar untuk mengatasi permasalahan di kelas. Pertemuan ke dua dilaksanakan pada hari Jumat tanggal 22 Januari 2021 dengan materi pelatihan berlatih menuliskan Pendahuluan dan Kajian Teori. Pertemuan ke tiga dilaksanakan pada hari Jumat tanggal 5 Februari 2021 dengan pelatihan penulisan Metode Penelitian.

Siklus II dilaksanakan pada hari Jumat tanggal 26 Februari 2021 dan 5 Maret 2021 dengan pelatihan editing dan revisi proposal penelitian tindakan Kelas yang telah dirancang guru pada siklus I. pertemuan ke tiga siklus II, guru mengumpulkan hasil akhir penyusunan proposal peneilitian tindakan kelas yang telah direvisi dan siap untuk dianalisis.

Penelitian ini dilaksanakan dalam 2 siklus. Setiap siklus terdapat 4 fase, perencanaan, pelaksanaan, pengamatan, dan evalusi.

\section{Siklus I}

1. Perencanaan

Ada dua tahap perencanaan pada penelitian ini. Tahap pertama adalah observasi awal tentang data kepangkatan guru pada UPTD SMPN 2 Kecamatan Luak. Selanjutnya pada tahap kedua adalah sebagai berikut : 1) Menentukan dan menetapkan guru sebagai subyek penelitian 2) Mempersiapkan materi tayang yang berisi panduan penulisan proposal penelitian tindakan kelas. 3) Mempersiapkan instrumen penilaian proposal PTK, dan 4) Menentukan jadwal pelaksanaan penelitian.

2. Pelaksanaan Tindakan

Pada pertemuan 1, peneliti mengumpulkan para guru untuk memperoleh pelatihan tentang bagaimana menyusun proposal penelitian tindakan kelas yang sesuai dengan lampiran buku 4 Pedoman Kegiatan Pengembangan Keprofesian Berkelanjutan dan Angka Kreditnya tahun 2019 dengan benar. Kegiatan dilanjutkan dengan mengidentifikasi permasalahan yang dihadapi guru di kelas dan mencarikan solusi terhadap permasalahan tersebut. Guru dibimbing menentukan dan memilih metoda, strategi atau pendekatan yang sesuai untuk mengatasi permasalahan yang dihadapi di kelas. Pada pertemuan ke dua, pelatihan dilanjutkan penulisan BAB I (Pendahuluan) dan BAB II (Kajian Teori) sesuai dengan judul yang dipilih guru, dan pada pertemuan ke tiga, peneliti membimbing guru merancang Metode Penelitian.

3. Pengamatan

Setelah pertemuan ke tiga, peneliti memberikan waktu kepada guru untuk menyelesaikan proposal penelitian tindakan kelas mereka sambil membimbing mereka bila diperlukan. Terakhir, guru mengumpulkan proposal PTK mereka untuk dinilai.

4. Refleksi

Setelah proposal PTK guru siklus 1 dinilai, maka peneliti menganalisis hasil temuan siklus I untuk dijadikan masukan dan tindakan yang dilaksanakan pada siklus II.

\section{Siklus 2}


1. Perencanaan tindakan

Perencanaan pada siklus II didasarkan pada temuan siklus I. Pada pelaksanaan tindakan siklus II, peneliti akan fokus pada permasalahan yang belum tuntas dicapai guru pada siklus I.

2. Pelaksanaan Tindakan

Pelaksananaan Tindakan pada siklus II berdasarkan temuan pada siklus I. Pada pertemuan 1, peneliti mengumpulkan para guru untuk memperoleh tentang penilaian Proposal PTK yang telah disusun guru pada siklus I. Peneliti menyampaikan keunggulan-keunggulan yang telah dicapai guru dan kelemahan-kelemahan tentang proposal PTK yang telah disusun guru. Pada pertemuan ke dua, guru dibimbing untuk merevisi dan melengkapi proposal mereka masing-masing dan pada pertemuan ke tiga, peneliti bersama guru berdikusi membicarakan manfaat yang diperoleh selama Workshop berlangsung.

3. Pengamatan

Peneliti menilai proposal PTK yang telah direvisi guru dengan menggunakan instrumen penilaian proposal seperti yang digunakan pada siklus I.

4. Refleksi

Peneliti dan guru secara bersama-sama melakukan perenungan tentang capaian yang diperoleh selama pelaksanaan Workshop terhadap kompetensi guru dalam menulis proposal tindakan kelas. Berdasarkan hasil temuan pada siklus II ini, peneliti memutuskan apakah penelitian dilanjutkan ke siklus III atau berhenti pada siklus II berdasarkan kepuasan peneliti terhadap temuan dan kriteria keberhasilan yang telah ditetapkan sebelumnya.

Instrumen penelitian tindakan sekolah ini adalah format penilaian proposal Penelitian Tindakan Kelas.

Tabel 1 <Instrumen Penilaian Proposal Penelitian Tindakan Kelas (PTK) Guru UPTD SMPN 2 Kecamatan Luak>

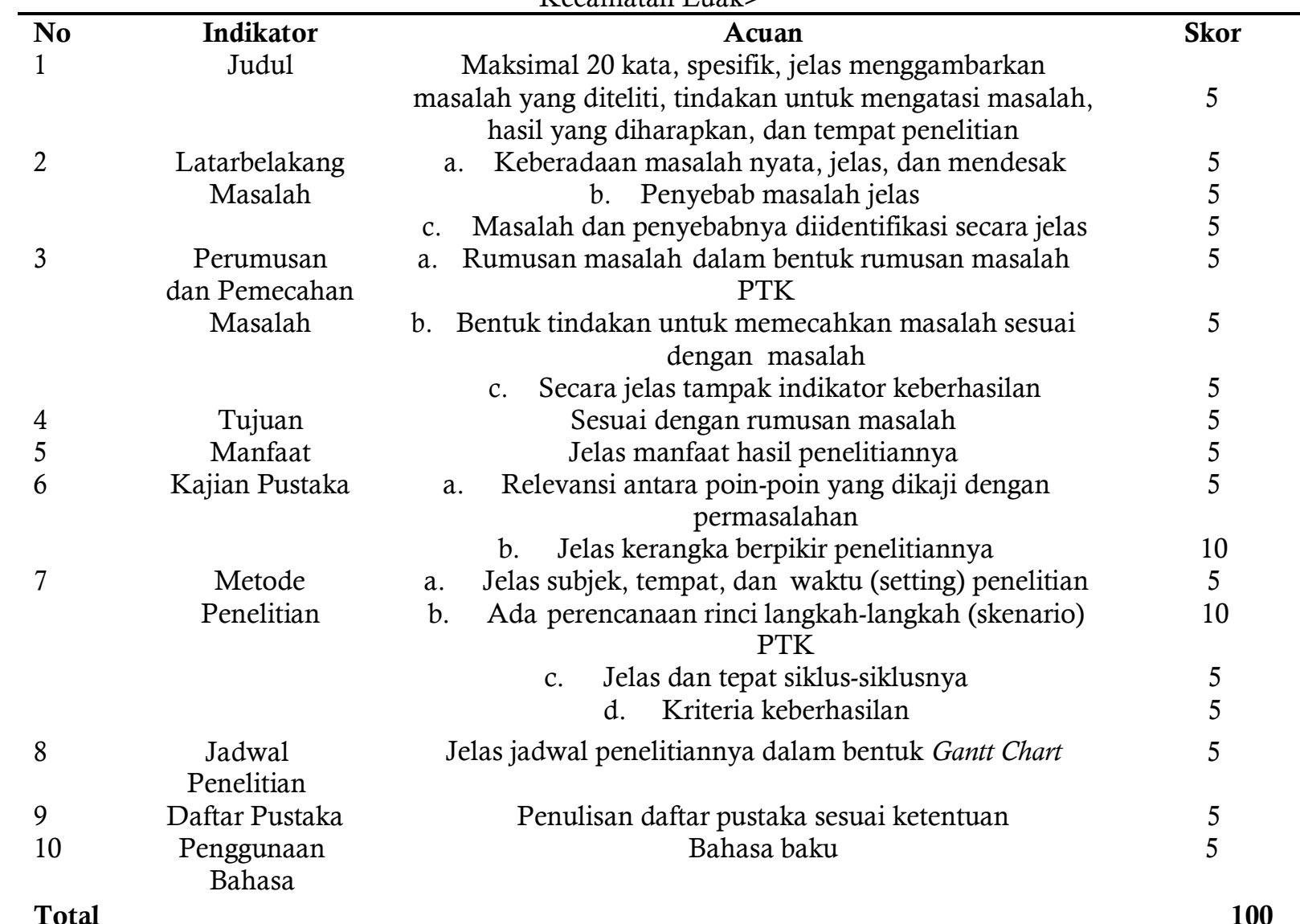

Total

Sumber: https://www.scribd.com/doc/303171150/Rubrik-Instrumen Penilaian-Proposal-Ptk

Data dikumpulkan melalui studi dokumen. Peneliti menganalisis proposal penelitian yang telah dibuat guru. Instrumen yang digunakan adalah lembar penilaian proposal penelitian tindakan kelas. Ada sepuluh poin yang dinilai pada instrumen tersebut yaitu: Judul, Pendahuluan, Perumusan dan Pemecahan Masalah, Tujuan Penelitian, Manfaat Penelitian, Kajian Pustaka, Metode Penelitian, Jadwal Penelitian, Daftar Pustaka, 
dan Penggunaan Bahasa. Peneliti mengkaji masing-masing proposal dengan menggunakan instrumen yang telah ditetapkan. Nilai maksimal perpoin adalah lima dan 10. sedangkan total nilai adalah 100.

Teknik pengolahan data adalah dengan menggunakan lembar penilaia proposal penelitian tindakan kelas dengan menggunakan persentase. Peneliti membagi kompetensi guru dalam membeuat proposal PTK berdasarkan empat kategori, yaitu perolehan nilai anatara $90 \leq \mathrm{A} \leq 100$ adalah Amat Baik (AB), $75 \leq \mathrm{B}<90$ adalah Baik (B), $60 \leq \mathrm{C}<74$ adalah Cukup (C), dan $<60$ adalah Kurang (K). Penelitian Tindakan sekolah ini dikatakan berhasil apabila guru mampu $80 \%$ membuat proposal PTK dengan mencapai nilai rata-rata minimal Baik.

\section{Hasil dan Pembahasan}

\section{Hasil}

Penelitian Tindakan Sekolah ini dilatarbelakangi oleh masih rendahnya motivasi guru UPTD SMPN 2 Kecamatan Luak untuk melengkapi bahan-bahan untuk kenaikan pangkat. Sebagai kepala sekolah yang baru mengemban tugas di sekolah ini merasa hal ini adalah sesuatu yang urgen untuk diselesaikan. Dari data yang diperoleh bahwa kebanyakan guru-guru membutuhkan angka kredit dalam Publikasi Ilmiah dan Karya Innovatif (PIKI) naik pangkat setingkat lebih tinggi. Namun guru-guru belum termotivasi untuk membuat PIKI untuk kenaikan pangkat dengan berbagai alasan.

Dari permasalahan tersebut di atas, maka peneliti tertarik untuk membimbing guru-guru untuk membuat proposal PTK agar mereka dapat melaksanakan penelitian dan melahirkan pulikasi ilmiah berupa hasil penelitian dan kemudian dipublikasikan dalam bentuk Jurnal bagi guru yang membutuhkan, yaitu guru yang akan naik pangkat dari Golongan IV.a ke IV.b.

Selanjutnya, peneliti sepakat dengan guru-guru yang belum naik pangkat dalam periode yang lama untuk melakukan bimbingan dalam bentuk Workshop dalam pembuatan proposal penelitian tindakan kelas. Temuannya dapat dipaparkan sebagai berikut:

\section{Siklus I}

1. Perencanaan (Planning)

Pada tahap perencanaan ini peneliti melakukan observasi dan menganalisa Daftar Urut Kepangkatan DUK) kondisi bulan Januari 2021 sebagai berikut:

Dari Daftar Urut Kepangkatan (DUK) guru UPTD SMPN 2 Kecamatan Luak pada kondisi bulan Januari 2021 di atas dapat dijelaskan bahwa ada 12 guru PNS selain Kepala Sekolah. Tiga orang guru memiliki pangkat dan golongan Pembina/IV.A Terhitung Mulai Tanggal (TMT) 04-01-2008, 01-102008 dan 01-10-2011. Tiga orang guru memiliki golongan III.D Terhitung Mulai Tanggal 01-04-2010, 01-10-2011, dan 01-04-2013. Satu orang guru dengan golongan III.C TMT 01-10-2012. Empat orang guru dengan golongan III.B dan satu orang guru dengan golongan III.A.

Berdasarkan data tersebut maka dapat disimpulkan bahwa guru-guru UPTD SMPN 2 Kecamatan Luak belum termotivasi untuk mengurus naik pangkat. Dari wawancara yang peneliti lakukan dengan guru bahwa guru belum siap untuk naik pangkat karena banyaknya tuntutan yang diperlukan, salah satunya adalah Publikasi Ilmiah dan Karya Innovatif. Mereka serentak menjawab bahwa belum terbiasa melakukan penelitian. Sulit untuk memilih judul dan menuliskan laporan penelitian. Oleh sebab itu, peneliti sebagai kepala sekolah memutuskan untuk melaksanakan bimbingan pembuatan proposal penelitian Tindakan kelas melalui Workshop.

Selanjutnya pada tahap kedua perencanaan adalah sebagai berikut: 1) Menentukan dan menetapkan guru sebagai subyek penelitian 2) Mempersiapkan materi tayang yang berisi panduan penulisan proposal penelitian tindakan kelas. 3) Mempersiapkan instrumen penilaian proposal PTK, dan 4) Menentukan jadwal pelaksanaan penelitian.

2. Pelaksanaan (Acting)

Pertemuan 1 dilaksanakan pada hari Jumat tanggal 22 Januari 2021 di ruang guru UPTD SMPN 2 Kecamatan Luak. Pada pertemuan ini, peneliti memberikan sosialisasi tentang Penelitian Tindakan kelas. PTK sangat dibutuhkan oleh guru untuk naik pangkat ke jenjang yang lebih tinggi. Oleh sebab itu guru wajib melaksanakan Penelitian Tindakan Kelas agar dapat naik pangkat. Kenapa harus PTK? Karena PTK dapat dilaksanakan guru tanpa mengganggu tugas pokok guru tesebut. Disamping itu dengan pelaksanaan PTK juga mudah dan murah dibandingkan dengan publikasi ilmiah lainnya. Nilai yang diperoleh dengan satu buah PTK juga besar yaitu 4 angka kredit. Waktu yang digunakan juga dapat disesuaikan oleh guru sendiri. Sementara publikasi ilmiah lainnya seperti buku perlu dana 
yang banyak untuk membayar editor dan biaya penerbitan. Disamping itu butuh waktu yang lama sesuai dengan ketersediaan editor dan jadwal penerbitan buku tersebut.

Selanjutnya, peneliti menjelaskan bagaimana menyusun proposal penelitian tindakan kelas yang sesuai dengan lampiran buku 4 Pedoman Kegiatan Pengembangan Keprofesian Berkelanjutan dan Angka Kreditnya tahun 2019 dengan benar. Kegiatan pelatihan dilanjutkan dengan meminta guru untuk menuliskan permasalahan-permasalahan yang dihadapi guru di kelas. Kemudian peneliti menayangkan beberapa pendekatan yang dapat digunakan guru untuk pemecahan permasalahan yang ditemukannya di kelas. Terakhir pada pertemuan pertama ini guru dibimbing membuat judul penelitian sesuai dengan permasalah yang dihadapi dan solusi pemecahan masalah yang dipilih.

Pada pertemuan ke dua, peneliti memberikan pelatihan dalam penulisan Pendahuluan dan Kajian Teori. Pertemuan ke dua dilaksanakan pada hari Jumat tanggal 29 Januari 2021. Pada kesempatan ini, peneliti membimbing peserta dalam penulisan Latar belakang masalah penelitian. Ada tiga komponen pokok yang harus ada dalam latar belakang masalah penelitian Tindakan kelas, kondisi ideal, kondisi nyata, dan solusi penyelesaian masalah, dari permasalahan yang ditemukan guru di kelas dikembangkan menjadi paragraph, dan kemudian mencantumkan solusi pemecahan masalah yang diangkat dalam PTK.

Kajian Teori yang dirancang guru adalah kajian yang ada keterkaitan dengan masalah penelitian yang diteliti. Kajian teori dirujuk guru dapat mengacu kepada buku-buku maupun kebijakankebijakan yang dikeluarkan pemerintah. Pada kesempatan ini, peneliti juga membimbing guru bagaimana penulisan Daftar Pustaka dari buku yang dirujuk pada Kajian Teori ini.

Dari pelaksanaan penelitian Tindakan sekolah ini, guru sebagai peserta belum dapat menyelesaikan penulisan Bagian Pendahuluan dan Kajian Teori pada jadwal yang telah ditentukan, maka peneliti meminta guru untuk menyelesaikannya di rumah maupun di sekolah di luar jam mengajar masingmasing.

Pada pertemuan ke tiga siklus I, peneliti membimbing peserta tentang penulisan metode penelitian dalam penelitian Tindakan kelas. Ada beberapa hal yang harus dicantumkan pada metode penelitian ini antara lain, jenis penelitian, subyek dan tempat penelitian, prosedur penelitian, instrument penelitian, pengolahan data penelitian, jadwal penelitian, dan kriteria keberhasilan penelitian.

Selama mengikuti Workshop, peserta nampak bersemangat dan berlatih menuliskan Bab III untuk penelitian tindakan kelas mereka. Peneliti sebagai pembimbing melatih mereka baik secara klasikal maupun individual. Namun waktu yang disediakan pada pertemuan ke tiga siklus I ini tidak cukup untuk menyelesaikan Metode Penelitian ini. Peneliti meminta guru peserta pelatihan untuk melanjutkan penyelesaiannya di rumah atau pada waktu-waktu senggang di sekolah agar proposal PTK mereka dapat dinilai.

Pertemuan ke tiga ini dilaksanakan pada tanggal 5 Februari 2021. Peserta diminta mengupulkan draf proposal PTK mereka pada tanggal 22 Februari 2021 untuk dilakukan penilaian kompetensi guru dalam membuat proposal PTK pada siklus I.

3. Pengamatan (Observing)

Pengamatan pada penelitian tindakan sekolah ini adalah pengamatan terhadap dokumen yang dihasilkan peserta. Dalam hal ini adalah draf proposal PTK yang telah dibuat guru selama siklus I berlangsung. Peneliti melakukanpengamatan dengan menggunakan instrumen penilaian propsal PTK yang telah dicantumkan pada Bab III penelitian ini.

Dari perolehan data di atas dapat dijelaskan bahwa semua guru yang mengikuti pelatihan penulisan proposal penelitian tindakan kelas telah menyelesaikan proposal penelitian mereka. Data menunjukkan bahwa rata-rata kompetensi guru adalah $62,125 \%$. Perolehan ini tergolong pada kompetensi Cukup $(60 \leq \mathrm{C}<74)$.

Pada penulisan judul, perolehan guru adalah 67,50 . Nilai yang diperoleh guru termasuk pada kategori Kurang. Hanya saja masih ada guru yang menuliskan judul belum mencantumkan tindakan untuk mengatasi masalah penelitian begitu juga dengan hasil yang diharapkan dari penelitian tersebut belum tergambar dengan nyata pada judul PTK. Selanjutnya untuk penulisan Latarbelakang masalah guru belum menguraikan Keberadaan masalah nyata, jelas, dan mendesak, penyebab masalah dan Masalah dan penyebabnya diidentifikasi secara jelas. Rata-rata skor perolehan guru adalah 9,75. Sementara Skor yang diharapkan adalah 15. Kompetensi guru pada poin ini adalah 65 dengan kategori Cukup. Berdasarkan tabel di atas dapat disimpulkan bahwa hampir seluruh poin yang dinilai, perolehan guru masih pada kategori cukup.

4. Perenungan (Reflecting)

Setelah semua data diolah dan dianalisis maka peneliti merenungkan hasil yang diperoleh untuk mengambil keputusan apakah tindakan akan dilanjutkan ke siklus II atau tidak. Berdasarkan situasi di saat Workshop dilaksanakan terlihat semangat dan partisipasi guru sangat tinggi dalam mengerjakan proposal yang diharapkan. Guru bekerja dengan gigih dan sering bertanya dan meminta arahan 
kepada peneliti tentang hal-hal yang mereka belum mengerti dan paham. Oleh sebab itu peneliti memutuskan untuk lanjut ke siklus II untuk melaksanakan Workshop dan membimbing guru dalam penyempurnaan proposal PTK mereka. Peneliti akan memfokuskan bimbingan pada kompetensi yang Siklus II belum dicapai guru.

1. Perencanaan (Planning)

Perencanaan siklus II diawali dengan penentuan jadwal Workshop. Di sini peneliti mendiskusikan hari dan tanggal pelaksanaan dengan semua guru peserta bimbingan. Maka diperolehlah pertemuan 1 pada hari Jumat tanggal 26 Februari 2021, Pertemuan 2 pada Hari Jumat tanggal 5 Maret 2021, dan pertemuan 3 pada hari Jumat tanggal 19 Maret 2021.

2. Pelaksanaan (Acting)

Pelaksanaan pertemuan 1 pada hari Jumat tanggal 26 Februari 2021 dengan kegiatan Diskusi dan perbaikan proposal. Pada kesempatan ini peneliti memaparkan kelemahan dan keunggulan proposal yang telah dirancang guru demi dilaksakan revisi dan penyempuranaan terhadap proposal PTK yang telah ditulis guru. Peneliti juga membimbing dan mengarahkan guru-guru dalam merevisi proposal tersebut.

Pertemuan 2 dilaksanakan pada Hari Jumat tanggal 5 Maret 2021 dengan kegiatan diskusi dan perbaikan proposal lanjutan. Pada kegiatan ini, peneliti memberikan kesempatan kepada guru peserta Workshop untuk bertanya dan merevisi proposal mereka sesuai dengan temuan yang telah peneliti paparkan pada pertemuan 1. Peneliti memberikan kesempatan dan waktu pada peserta untuk menyelesaikan revisi proposal mereka dan dikumpulkan untuk diteliti dan dinilai untuk siklus 2 dari PTS ini. Peneliti memberikan kesempatan pada mereka untuk menyelesaikan propsal pada pertemuan 2 ini. Bagi peserta yang telah selesai perbaikan boleh mengumpulkan proposal dan pertemuan 3 tidak dilaksanakan lagi,

Pertemuan 3 pada hari Jumat tanggal 19 Maret 2021 adalah pengumpulan proposal PTK. Namun pertemuan 3 ini tidak lagi dilaksanakan karena peserta telah menyelesaikan proposal PTK mereka pada pertemuan 2 .

3. Pengamatan (Observing)

Dari temuan pada penilaian proposal PTK yang disusun guru dapat dijelaskan bahwa rata-rata perolehan guru dalam penyusunan proposal PTK adalah 89,92\% dengan kategori Baik. Secara umum semua kategori yang dikembangkan selama mengikuti Workshop dapat diselesaikan oleh guru dengan baik. Ada tiga kategori yang diperoleh guru dengan sempurna yaitu penulusan judul penelitian, penetapkan tujuan penelitian, dan penentuan jadwal penelitian. Indikator yang lain diperoleh nilai antara $80 \%-94,17 \%$. Dengan demikian dapat dijelaskan bahwa terjadi peningkatan kompetensi guru pada penyusunan proposal penelitian tindakan kelas siklus II ini.

Pada dasarnya semua jenis tindakan yang dilakukan pada siklus II ini sama dengan siklus I, hanya saja terdapat penyempurnaan/perbaikan sesuai dengan harapan. Untuk mendapatkan gambaran nyata tentang kegiatan siklus II dapat diuraikan sebagai berikut: Proses pelaksanaan Workshop dinyatakan telah berhasil jika nilai rata-rata yang diperoleh guru sebagai peserta Workshop penyusunan proposal penelitian tindakan kelas minimal $\leq 75$ dengan kategori Baik dicapai oleh guru $\leq 80 \%$.

4. Perenungan (Reflecting)

Perenungan dilaksanakan setelah peneliti memperoleh hasil dari penilaian proposal penelitian Tindakan kelas yang disusun oleh guru-guru UPTD SMPN 2 Kecamatan Luak. Dari temuan tersebut diperoleh nilai rata-rata sebesar 89,92. Perolehan ini tergolong ke dalam kategori Baik. Berdasarkan temuan tersebut maka peneliti memutuskan bahwa penelitian tindakan sekolah ini dihentikan pada siklus II, karena kriteria keberhasilan penelitian telah tercapai.

\section{Pembahasan}

Penelitian Tindakan Kelas adalah penelitian yang dilaksanakan oleh guru pada kelas yang diampunya. Tujuan pelaksanaan PTK bagi guru adalah memperbaiki kelemahan dan kekurangan baik cara mengajar guru maupun hasil yang diharapkan terhadap peserta didik. Oleh sebab itu, guru berkewajiban memperbaiki dan meningkatkan cara mengajar agar peserta didik tidak bosan belajar. Disamping itu, PTK adalah sebuah prestasi bagi guru dalam kenaikan pangkat. Dengan melaksanakan PTK maka guru memiliki 4 poin pada bagian Publikasi Ilmiah yang sangat diperlukan bagi kenaikan pangkat guru.

Dalam rangka peningkatan kompetensi guru dalam menyusun proposal penelitian Tindakan kelas, maka peneliti melaksanakan Workshop di UPTD SMPN 2 Kecamatan Luak. Ada delapan orang guru sebagai peserta 
dalam pelatihan ini. Pelatihan ini dihadiri oleh guru-guru PNS yang berminat untuk melaksakan penelitian kelas. Jadi tidak ada keharusan untuk bergabung pada pelatihan ini. Penelitian dilaksanakan selama dua siklus. Hasil yang diperoleh dapat dibahas sebagai berikut:

\section{Peningkatan Kompetensi Guru Menyusun Proposal PTK}

Dari temuan penelitian dapat disajikan data dari penilaian proposal PTK yang disusun guru sebagai berikut:

Tabel 2 <Peningkatan Kompetensi Guru Menyusun Proposal PTK (Indikator)>

\begin{tabular}{lccc}
\hline Indikator & Siklus I & Siklus II & Peningkatan \\
Judul & 67,50 & 100,00 & 32,50 \\
Latarbelakang Masalah & 65,00 & 83,33 & 18,33 \\
Perumusan dan Pemecahan Masalah & 60,00 & 94,17 & 34,17 \\
Tujuan & 57,50 & 100,00 & 42,50 \\
Manfaat & 62,50 & 85,00 & 22,50 \\
Kajian Pustaka & 61,67 & 86,67 & 25,00 \\
Metode Penelitian & 60,00 & 90,00 & 30,00 \\
Jadwal Penelitian & 60,00 & 100,00 & 40,00 \\
Daftar Pustaka & 75,00 & 80,00 & 5,00 \\
Penggunaan Bahasa & 60,00 & 80,00 & 20,00 \\
Rata-rata & $\mathbf{6 2 , 9 2}$ & $\mathbf{8 9 , 9 2}$ & $\mathbf{2 7 , 0 0}$ \\
\hline
\end{tabular}

Dari tabel di atas terlihat perbedaan yang nyata tentang kompetensi guru menyusun proposal PTK. Ratarata nilai yang diperoleh pada siklus I adalah sebesar 62,92\% kemudian pada siklus II beronah mejadi 89,92\%. Secara nyata terjadi peningkatan kompetensi guru dalam menyusun proposal PTK di UPTD SMPN 2 Kecamatan Luak.

Secara rinci dapat dipaparkan bahwa pada indikator penulisan judul penelitian pada siklus I, penulisan judul penelitian pada proposal yang disusun guru masih belum lengkap. Ada beberapa judul penelitian yang belum mencantumkan tindakan yang akan dilakukan. Pada indikator lainnya, penulisan Latarbelakang masalah terjadi peningkatan sebesar $18,33 \%$. Begitu juga pada indikator lainnya, semuanya terjadi peningkatan kompetensi guru dalam penyusunan proposal penelitian tindakan kelas. Selanjutnya, data juga dapat disajikan dalam bentuk grafik di bawah ini:

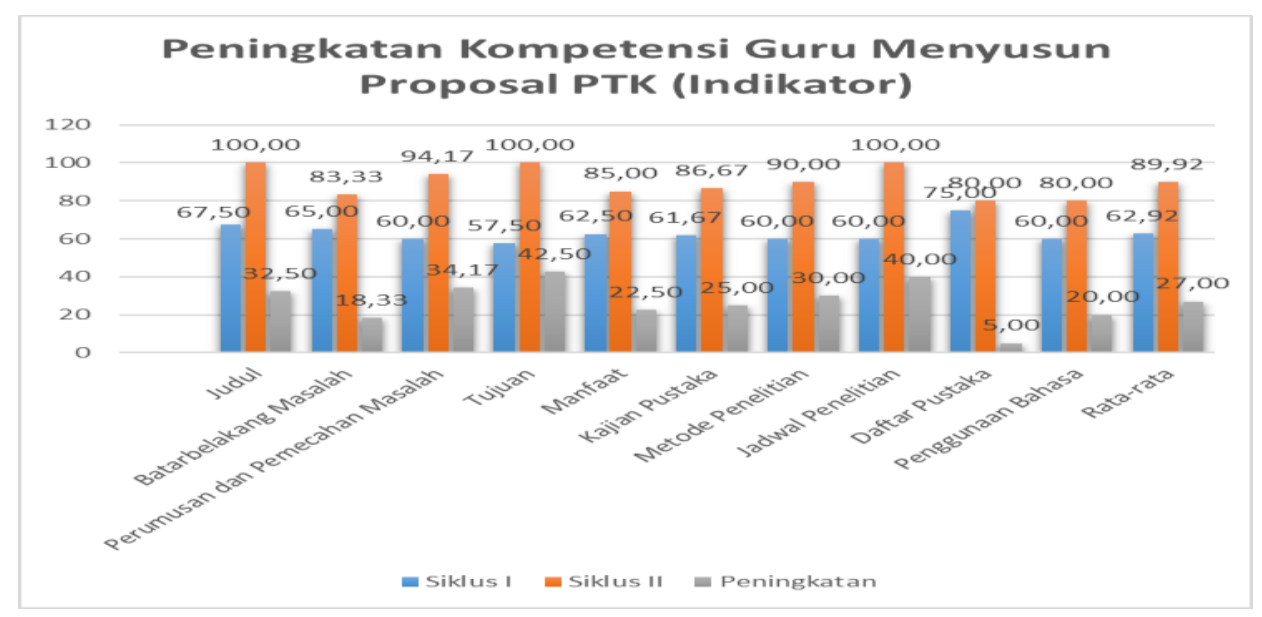

Grafik 1 <Peningkatan Kompetensi Guru Menyusun Proposal PTK (Indikator)>

Dari grafik di atas terlihat bahwa terjadi peningkatan pada kompetensi guru menyusun proposal PTK dari Siklus I ke Siklus II. Dari data diperoleh Peningkatan penyusunan Judul PTK adalah sebesar 15,63\%. Penulisan Latarbelakang Masalah meningkat sebesar 18,33\%. Perumusan dan Pemecahan Masalah meningkat 34,17\%. Peningkatan pada penyusunan tujuan dan Manfaat penelitian adalah sebesar 42,50\% dan 22,50\%. Penulisan Kajian Pustaka meningkat dari 61,67\% menjadi 86,67\%. Peningkatan yang terendah adalah pada penulisan Daftar Pustaka sebesar 5,00\% dan peningkatan tertinggi adalah pada indikator penyusunan Jadwal Penelitian. Terakhir secara rata-rata peningkatan kompetensi guru dalam menyusun proposal penelitian dari Siklus I ke Siklus II adalah 25,31\%. 


\section{Peningkatan Nilai Guru Menyusun Proposal PTK}

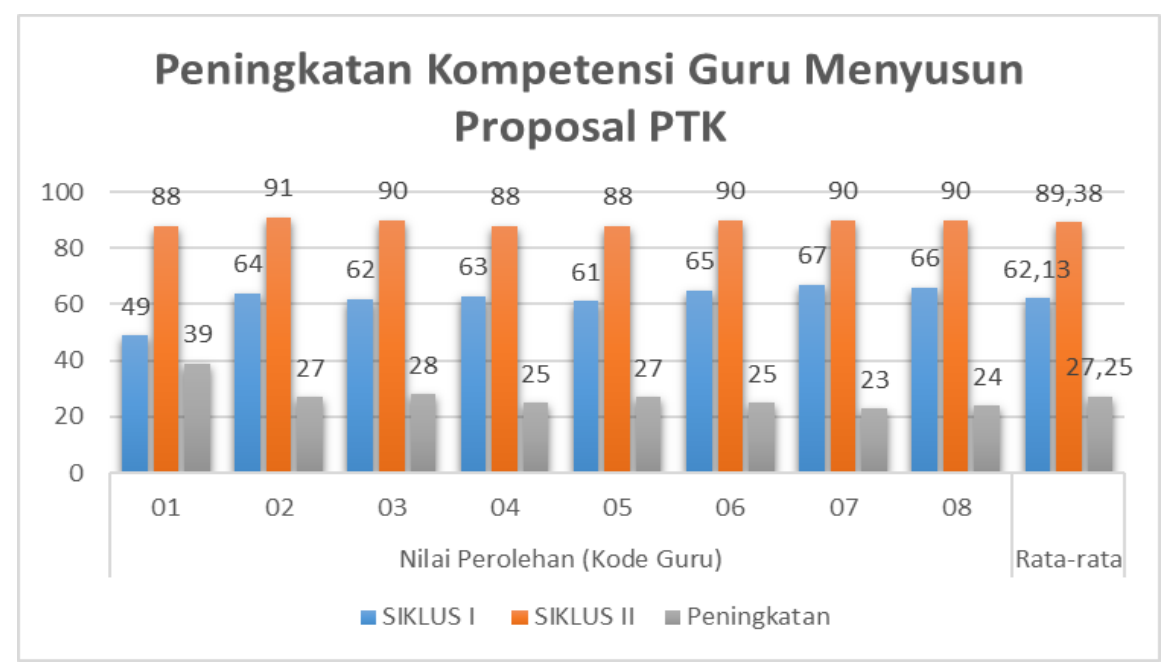

Grafik 2 <Peningkatan Kompetensi Guru Menyusun Proposal PTK>

Pada grafik 2 di atas dapat dilihat peningkatan kompetensi guru menyusun proposal PTK terjadi dari rentang nilai 23\%-39\%. Peningkatan tertinggi terjadi terhadap guru dengan kode 01 yaitu 39\%. Perolehan pada siklus I adalah $49 \%$ dan pada sikulus II menjadi $88 \%$. Peningkatan terrendah terjadi pada guru dengan kode 07. penilaian proposal pada siklus I adalah $67 \%$. Hal ini berarti sebagaian besar proposal yang telah disusun oleh guru tersebut sudah mendekati kategori Baik. Pada siklus II nilai yang diperoleh adalah 90\% dengan kategori Baik. Peningkatan kompetensi yang dicapai guru 07 adalah 23\%. Rata-rata peningkatan kompetensi guru secara umum menyusun proposal penelitian tindakan kelas adalah $27,25 \%$.

\section{Simpulan}

Berdasarka temuan dari Penelitian Tindakan Sekolah (PTS) ini dapat dijelaskan bahwa Workshop sangat efektif dalam upaya meningkatkan kompetensi guru SMPN 2 Kec. Luak penyusunan proposal Penelitian Tindakan Kelas (PTK). Proses pembimbingan penyusunan proposal Penelitian Tindakan Kelas (PTK) dalam bentuk Workshop dilaksanakan dalam dua Siklus. Melalui Workshop mampu merubah kompetensi guru SMPN $2 \mathrm{Kec}$. Luak dalam menyusun proposal PTK dengan hasil sebagai berikut:

1. Indikator keberhasilan dalam Penelitian Tindakan Sekolah (PTS) ini pada siklus II sudah tercapai, guru mampu $80 \%$ membuat proposal PTK dengan mencapai nilai rata-rata minimal Baik. Perolehan hasil penelitian tercapai $100 \%$ guru dapat menyusun proposal PTK dengan Baik.

2. Peningkatan Kompetensi guru berdasarkan indikator pada instrumen penelitian meningkat sebesar $25,31 \%$

3. Peningkatan kompetensi individu guru meningkat dengan rata-rata $27,25 \%$.

4. Berdasarkan kesimpulan di atas, maka dapat diberikan beberapa saran sebagai berikut:

5. Bagi kepala sekolah untuk menerapkan pelatihan berbentuk Workshop sebagai salah satu pembinaan kenaikan pangkat guru.

6. Bagi guru agar dapat menerapkan ilmu yang diperoleh untuk meningkatkan dan mengembangkan kompetensi profesionalnya, karena itu merupakan bagian tidak terpisahkan dari sistem pembelajaran.

7. Bagi peneliti selanjutnya dapat melaksanakan pelatihan pada kompetenesi yang lain untuk membantu guru mengatasi permasalahan yang mereka hadapi dalam pembelajaran maupun karier guru.

\section{Referensi}

Arikunto, Suharsimi. 2006. Prosedur Penelitian Suatu Pendekatan Praktik. Jakarta: Rineka Cipta.

Arikunto, S. 2010. Prosedur Penelitian Suatu Pendekatan Praktik. Jakarta: Rineka Cipta

Kemendikbud. 2016. Pedoman Kegiatan Pengembangan Keprofesian Berkelanjutan Bagi Guru Pembelajar. Jakarta:

Direktorat Jenderal Guru Dan Tenaga Kependidikan

Kemendikbud. 2019. Pedoman Kegiatan Pengembangan Keprofesian Berkelanjutan Dan Angka Kreditnya. Jakarta:

Direktorat Jenderal Guru Dan Tenaga Kependidikan 
Mendikbud. 2018. Peraturan Menteri Pendidikan dan Kebudayaan Republik Indonesia No. 15 Tahun 2015 tentang Pemenuhan Beban Kerja Guru, Kepala Sekolah, dan Pengawas Sekolah, Jakarta: Mendikbud Waitlem dan Risman. 2017. Praktik Praktis Penulisan Karya Tulis Ilmiah untuk Guru. Padang. CV, Visigraf 